\title{
Spatial and temporal variation of benthic macroinvertebrate assemblages during the glacial melt season in an Italian glacier-fed stream
}

\author{
A. Scotti - D. Jacobsen - U. Tappeiner - R. Bottarin
}

Received: 18 December 2017/Revised: 19 July 2018/ Accepted: 4 August 2018/Published online: 16 August 2018

(C) The Author(s) 2018

\begin{abstract}
The biodiversity of glacier-fed streams is particularly threatened by climate change, emphasising the need of monitoring these sentinel systems. The glacier-fed Saldur stream is an International Long Term Ecological Research (ILTER) site in the Italian Central Eastern Alps. Here, we sampled benthic macroinvertebrates and measured environmental variables (discharge, suspended solids, conductivity, water temperature, and channel stability) five times at six sites (5-11 km from the glacier) during an entire glacial melt season (April-September). Our main objectives were (1) to elucidate relationships between the abiotic variables and the faunal composition, (2) to
\end{abstract}

Handling editor: Marcelo S. Moretti

Electronic supplementary material The online version of this article (https://doi.org/10.1007/s10750-018-3731-8) contains supplementary material, which is available to authorized users.

A. Scotti $(\bowtie) \cdot$ U. Tappeiner $\cdot$ R. Bottarin

Institute for Alpine Environment, EURAC Research,

Drususallee 1, 39100 Bozen, Italy

e-mail: alberto.scotti@eurac.edu

A. Scotti - D. Jacobsen

Freshwater Biology Section, Department of Biology,

University of Copenhagen, Universitetsparken 4,

2100 Copenhagen $\varnothing$, Denmark

\section{A. Scotti - U. Tappeiner}

Institute of Ecology, University of Innsbruck,

Sternwartestraße 15, 6020 Innsbruck, Austria quantify and compare the spatial and temporal variability of the faunal community, and (3) to assess the composition of the benthic macroinvertebrate community in relation to conceptual models. Hosting a higher number of individuals and more diverse communities at sites with reduced glacial influence, the Saldur stream fitted well in the framework of conceptual models. Nevertheless, the spatial variability of the fauna was higher than the temporal variability. This study presents an initial characterisation of the benthic faunal assemblages in the Saldur stream, constituting a reference point for future analyses dealing with potential disruptive factors introduced by climate change and upcoming hydroelectric power production on this stream.

Keywords ILTER · Italian Alps · Faunal variability · Monitoring $\cdot$ Invertebrates $\cdot$ Macrozoobenthos

\section{Introduction}

High Alpine glacier-covered regions are expected to be particularly exposed to climate change effects in the next decades (Schädler \& Weingartner, 2010; Jordan et al., 2016). Consequently, streams draining Alpine areas are generally identified as one of the environments most sensitive to climate change (Füreder et al., 2002; Viviroli \& Weingartner, 2008; 
Jiménez Cisneros et al., 2014). This is particularly true for glacier-fed streams and rivers. The forecasted changes in climate will eventually result in the disruption of the current sediment budgets and hydrographs (Milner et al., 2017; Brown et al., 2018). More specifically, the discharge peak of glacier-fed rivers may shift from the summer towards the spring season, while the total annual runoff will increase in the first phase but decrease in the long term (Milner et al., 2009; Huss et al., 2010; Huss, 2011; Huss \& Hock, 2018).

Changes in the abiotic environment will have implications for aquatic biota. Locally, the decreasing percentage of glacial cover in a catchment increases the taxonomic richness of algae (Rott et al., 2006) and of benthic aquatic macroinvertebrates (Brown et al., 2007c; Milner et al., 2008; Jacobsen et al., 2010). Nevertheless, from a long-term perspective at the global level, the shrinkage of glaciers and the loss of permanent snow (Huss et al., 2017) may eventually lead to the extinction of several alpine freshwater taxa (Jacobsen et al., 2012; Finn et al., 2013; Giersch et al., 2015).

Given the expected changes of the cryosphere, monitoring these susceptible habitats and the organisms inhabiting them becomes highly important (Brown et al., 2006). Indeed, Khamis et al. (2014) suggested the use of invertebrates as indicators of environmental change in relation to glacial retreat, while Giersch et al. (2017) clearly linked the loss of alpine insects to the consequences of climate change, both stressing the need for further research.

In recent years, glacier-fed streams and rivers have been studied intensively in terms of both abiotic environments and the temporal and spatial factors influencing the benthic macroinvertebrate assemblage patterns and dynamics (e.g. Maiolini \& Lencioni, 2001; Robinson et al., 2001; Snook \& Milner, 2001; Füreder, 2007; Finn et al., 2013; Cauvy-Fraunié et al., 2015, 2016; Khamis et al., 2016). However, studies directly comparing faunal variability at spatial versus temporal scales with high resolution are scarce (but see Füreder et al., 2001; Schütz et al., 2001; Brown et al., 2007a).

With the goal of deepening the knowledge of glacier-fed stream ecosystems in the Italian Alps, the Saldur stream, a glacier-fed stream in the Italian Central Eastern Alps, is particularly interesting due to the intensification of monitoring and sampling activities in the entire catchment beginning in 2015 . Indeed, between spring 2014 and autumn 2015, a "run-of-river" (ROR) hydropower plant designed to produce $3200 \mathrm{~kW}$ a year was built at $\sim 2000 \mathrm{~m}$ a.s.l., and the stream and its catchment became part of the International Long Term Ecological Research (ILTER) network (site IT-25) in 2014.

Considering the 2015 melting season, the objectives of the present study were (1) to elucidate the relationships between a set of abiotic variables of the glacier-fed stream varying in time and space and the composition of macroinvertebrate assemblages, (2) to quantify and compare the effects of space (i.e. the positions of the sampling sites, 5-11 km from the glacier) and time (i.e. the time of sampling) factors on the community structure of the fauna, and (3) to assess and to characterise the composition of the benthic macroinvertebrate community and abiotic parameters in the Saldur stream before the implementation of the hydropower plant.

We hypothesise that (1) the density and diversity of macroinvertebrates is highest when and where environmental harshness is low (low glacial influence). Further, we suggest that (2) the benthic macroinvertebrate assemblage responds more to season than to site variation (month-to-month variation is higher than site-to-site variation), due to the high variability of environmental conditions during the glacial melt season. Finally, (3) as the stream flow is still unaffected in terms of quality and quantity, we assume that faunal assemblages, as well as environmental parameters, fit into the conceptual model for spatial and temporal patterns described previously (Milner et al., 2001; Füreder, 2007; Brown et al., 2007b).

\section{Materials and methods}

\section{Study area}

The Saldur stream drains the Matscher Valley, an eastern side valley of the Vinschgau Valley in South Tyrol, Italy. The catchment $\left(101 \mathrm{~km}^{2}\right)$ has been an ILTER site since 2014 (IT-25), located within the

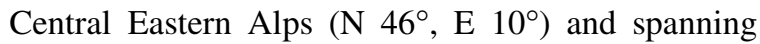
between $921 \mathrm{~m}$ a.s.l. and $3738 \mathrm{~m}$ a.s.l. The geology of the area is characterised by the presence of gneisses, mica gneisses, and schists (Habler et al., 2009). The climate is relatively dry and has a total annual 
precipitation of approximately $500 \mathrm{~mm}$ measured at $1570 \mathrm{~m}$ a.s.l., with a clear distribution showing a minimum in winter and a maximum in summer (source: Hydrographical Office of the Autonomous Province of Bozen). The land cover is a mixture of bare soil and rocks in the upper part of the catchment, while the lower part is characterised by more forests, pastures, and grasslands. The anthropogenic activities in the catchment are mainly limited to agriculture (primarily animal husbandry, mowing, and cultivation of strawberries).

The Saldur stream originates from the Matsch Glacier, whose surface area decreased from $2.8 \mathrm{~km}^{2}$ in 2006 (Galos \& Kaser, 2014) to $2.2 \mathrm{~km}^{2}$ in 2013. The stream has some small, intermittent, groundwater-fed tributaries. The hydrological dynamics characterising the stream are nivo-glacial, with the snow melting generally occurring between June and July and the glacial melting occurring in August. At a gauging station at $1632 \mathrm{~m}$ a.s.l. run by the Hydrographical Office of the Autonomous Province of Bozen, typical baseflow conditions show discharge values around $0.6 \mathrm{~m}^{3} / \mathrm{s}$. During the melt season, these values span between $5 \mathrm{~m}^{3} / \mathrm{s}$ and $10 \mathrm{~m}^{3} / \mathrm{s}$, with peaks up to $15 \mathrm{~m}^{3} / \mathrm{s}$ in the case of storm events.

Between spring 2014 and autumn 2015, a flowing water hydropower plant, having its weir at $2012 \mathrm{~m}$ a.s.l. and producing up to $3200 \mathrm{~kW}$ a year, was built. Hydroelectric power production started in December 2015, with the current concession (2017) allowing a production of $1600 \mathrm{~kW}$ a year.

\section{Study design}

For the present study, six sites along the Saldur stream were chosen. Sites $2 \mathrm{~A}, 2 \mathrm{~B}$, and $2 \mathrm{C}$ were chosen adjacent to each other with a distance of 100-160 m, to be able to assess the impact of the hydropower plant in relation to the position of the weir in the near future. For the others, the denomination of the sites preserved the names assigned during previous monitoring campaigns (Fig. 1).

The investigated stretch of stream from site 1 to site 3 was $6.2 \mathrm{~km}$ long, and the altitude ranged between $2030 \mathrm{~m}$ a.s.l. at site 1 and $1645 \mathrm{~m}$ a.s.l. at site 3. The altitude and position of each site relative to the glacier are reported in Table 1.

On a monthly basis, a set of environmental variables and macroinvertebrate samples was collected at all sites during 2-day periods from April 2015 to September 2015. Each sample is identified by the site code coupled with the month of collection (AM April/May, JE June, $J Y$ July, $A U$ August, $S E$ September).

Abiotic variables

Spot measurements of water temperature (tem) with an alcohol thermometer were recorded at each site. In addition, water samples were collected in 3 polyethylene (PE) bottles of $100 \mathrm{ml}$ and in $3 \mathrm{PE}$ bottles of 11 to assess conductivity (con) and suspended solids (ss), respectively. The channel stability (pfa) was estimated for each site by calculating the bottom component of the Pfankuch index (Pfankuch, 1975). Data on the hydrological regime, namely discharge (dis), were retrieved at site 3 using a stream gauging station, logging values every $10 \mathrm{~min}$.

In the laboratory, electrical conductivity (EC, at $25^{\circ} \mathrm{C}$ ) was measured using an EC metre (COND7; XS Instruments, Carpi, Italy) calibrated with a standard solution of $84 \mu \mathrm{S} / \mathrm{cm}$. Suspended solids were measured after $30 \mathrm{~min}$ of sedimentation of each water sample in a plastic Imhoff cone (APAT \& IRSA-CNR, 2003), using the volume of wet particles $\left(\mathrm{ml} \mathrm{l}^{-1}\right)$ as surrogate. As a final value for each site during the five different sampling events, the average of the three water samples for conductivity and suspended solids was calculated.

As additional environmental variables, we considered the following for each site: chainage of the sites (cha), defined as the distance from the glacier snout that was calculated with ArcGIS (Esri, 2014) and the Glacial Index (gla), an index of glacial influence that was calculated by combining glacier size with the distance from the glacier terminus, as defined by Jacobsen \& Dangles (2012).

\section{Macroinvertebrates}

Benthic macroinvertebrates were sampled at each of the six stream sites on five occasions. On each sampling event, we collected a total of 12 Surber samples $\left(0.0506 \mathrm{~m}^{2}\right.$, mesh size $\left.500 \mu \mathrm{m}\right)$ at random, covering the main substrate types present at each site. Four Surber samples were combined into one sample such that each sampling from a site provided three separate replicate samples. All replicates were 


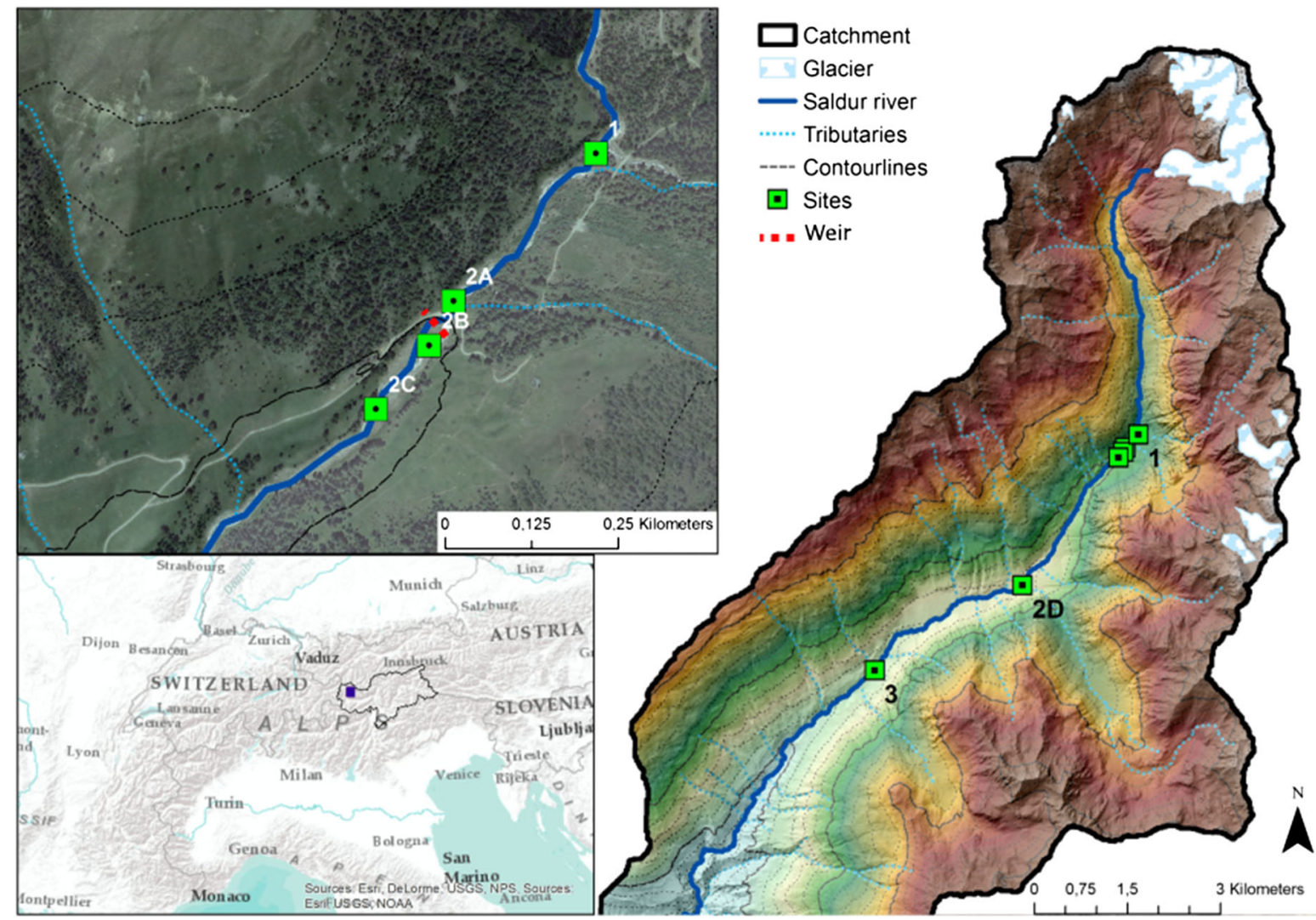

Fig. 1 Map and location of the sampling sites along the Saldur stream in Central Eastern Alps (N $46^{\circ}$, E $\left.10^{\circ}\right)$. The upper left picture shows a magnification of the area included in the black perimeter on the right

labelled and preserved in the field in $70 \%$ ethanol. For data treatment, the three separate replicates from one site were summed together, resulting in the sample codes mentioned before (e.g. 1-AM, 2A-AM).

In the laboratory, Surber samples were sorted, and the fauna were identified to the lowest possible taxonomic level under a stereoscopic microscope at $\times 15$ magnification, referring to Campaioli et al. (1994) and Sansoni \& Ghetti (1998). Of the 27 total taxa, 9 were classified to the genus or species level and 18 (including chironomids) to the family level.

Data treatment and statistical analysis

The benthic macroinvertebrate community was first analysed by calculating density, taxonomic richness, the Shannon-Weaver index $\left(\mathrm{H}^{\prime}\right)$, the Simpson dominance index (1-D), and the Pielou evenness index (J) for each site and month. Average agglomerative clustering through the Unweighted Pair-Group
Method using Arithmetic averages (UPGMA) was applied to the faunal data after chord transformation, with the number of clusters defined by fusion levels (Legendre \& Gallagher, 2001).

To compare the effects of time and space, all possible pairs of elements (months or sites, not mixed) were tested using a non-parametric Friedman test (with Bonferroni correction). We tested for differences in the faunal indices, the abiotic variables, and the taxa that scored more than 200 findings throughout the sampling period (seven in total). The same dataset was explored for Pearson correlations, again considering all possible pairs of sites and months.

Faunal metrics (ind. $/ \mathrm{m}^{2}$, taxonomic richness, \% EPT, $\left.\mathrm{H}^{\prime}, 1-\mathrm{D}, \mathrm{J}\right)$ were further analysed by agglomerating samples on the basis of months and sites. Additionally, a coefficient of variation (CV) for each metric linked to each site or month was calculated (e.g. agglomerating all the samples collected throughout the season at a site or agglomerating all the samples 


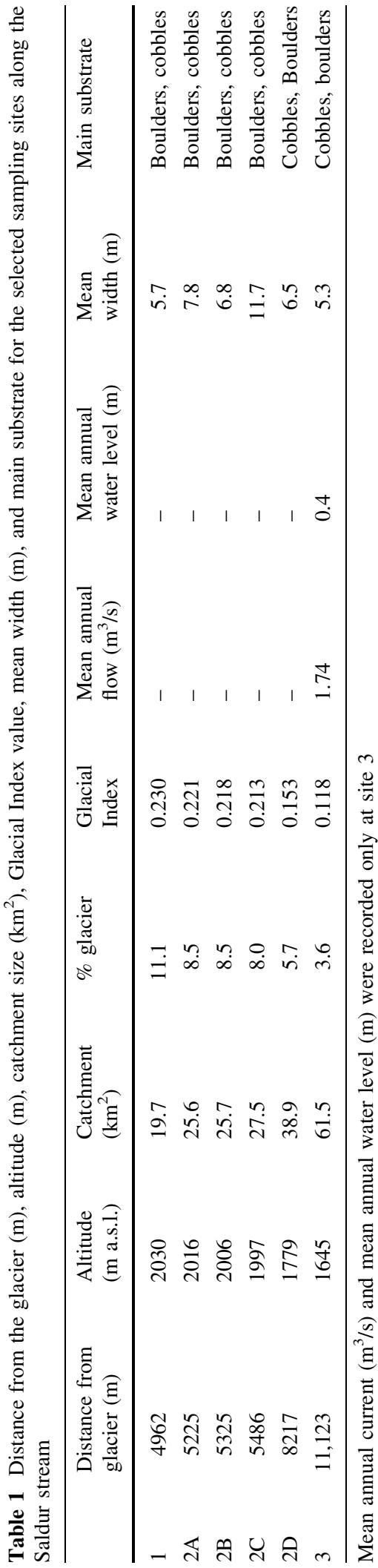

collected throughout the study site at a specific sampling occasion).

Finally, a canonical correspondence analysis (CCA) was computed to analyse the relationship between the raw fauna and environmental data matrices. The overall analysis and the axes were tested through a Monte Carlo permutation test $(n=999)$. The resulting biplots were plotted using scaling 1 and scaling 2. The former approximates the position of the samples along the environmental variables (Borcard et al., 2011), and the latter shows the optimum taxa along a set of quantitative environmental factors (Borcard et al., 2011), emphasising relationships among taxa (Legendre \& Legendre, 2012).

All data were processed using $\mathrm{R}$ software, version 3.3.0 (R Core Team, 2016), using the packages ade4 (Dray \& Dufour, 2007), ellipse (Murdoch \& Chow, 2018), FactoMineR (Le et al., 2008), MASS (Venables \& Ripley, 2002), packfor (Dray et al., 2016), and vegan (Oksanen et al., 2018).

\section{Results}

Abiotic conditions

Discharge, suspended solids, conductivity, and temperature showed clear seasonal patterns in all sites related to glacial-melting dynamics, with significant differences (Friedman tests, $P<0.05$ ) among the sampling events, particularly when considering the month of August (Tables 2 and 3).

Discharge was only weakly correlated with temperature $(r=-0.383, P<0.05)$ when considering all sampling events during the entire study. Nevertheless, in August, when glacial melt was prominent, discharge was highly correlated with suspended solids $(r=0.964, P<0.01)$, conductivity $(r=-0.852$, $P<0.05)$, and temperature $(r=0.993, P<0.01)$ across all six sites. Suspended solids and conductivity ( $r=-0.630, P<0.01$ ) were correlated for all the sampling events, as well as suspended solids versus temperature $(r=0.587, P<0.01)$ and conductivity versus temperature $(r=-0.622, P<0.01)$.

The Glacial Index decreased with increasing distance from the glacier snot (cha) $(r=-0.990$, $P<0.001)$. Values of Glacial Index overall showed a limited glacial influence in absolute terms (Table 1). The Pfankuch index showed a similar trend, increasing 
Table 2 Mean values of the environmental parameters directly collected in the Saldur stream, measured at the sampling sites

\begin{tabular}{|c|c|c|c|c|c|c|c|c|c|c|c|c|c|}
\hline & \multicolumn{4}{|l|}{ AM } & \multicolumn{4}{|l|}{ JE } & \multicolumn{5}{|l|}{ JY } \\
\hline & ss & con & tem & pfa & ss & con & tem & pfa & ss & con & & tem & pfa \\
\hline \multicolumn{14}{|c|}{ Sampling event } \\
\hline 1 & $0.07 \pm 0.03$ & $298.7 \pm 3.05$ & 6 & 47 & $0.14 \pm 0.05$ & $202.7 \pm 2.52$ & 6 & 45 & $0.17 \pm 0.01$ & \multicolumn{2}{|c|}{$183.0 \pm 0.00$} & 6 & 45 \\
\hline $2 \mathrm{~A}$ & $0.06 \pm 0.02$ & $297.0 \pm 5.20$ & 5 & 47 & $0.20 \pm 0.000$ & $201.7 \pm 0.58$ & 6 & 47 & $0.10 \pm 0.00$ & \multicolumn{2}{|c|}{$211.3 \pm 12.86$} & 8 & 47 \\
\hline $2 \mathrm{~B}$ & $0.16 \pm 0.01$ & $291.3 \pm 1.53$ & 6 & 47 & $0.11 \pm 0.01$ & $213.0 \pm 1.00$ & 6 & 45 & $0.22 \pm 0.04$ & \multicolumn{2}{|c|}{$189.7 \pm 0.58$} & 10 & 45 \\
\hline $2 \mathrm{C}$ & $0.16 \pm 0.05$ & $283.7 \pm 0.58$ & 5 & 47 & $0.11 \pm 0.01$ & $213.3 \pm 1.52$ & 5 & 45 & $0.52 \pm 0.02$ & \multicolumn{2}{|c|}{$160.3 \pm 1.53$} & 10 & 45 \\
\hline $2 \mathrm{D}$ & $0.14 \pm 0.01$ & $220.7 \pm 4.62$ & 6 & 43 & $0.05 \pm 0.00$ & $222.7 \pm 0.58$ & 7 & 43 & $0.90 \pm 0.02$ & \multicolumn{2}{|c|}{$153.0 \pm 1.00$} & 10 & 41 \\
\hline 3 & $0.13 \pm 0.04$ & $214.0 \pm 7.94$ & 6 & 34 & $0.11 \pm 0.01$ & $205.3 \pm 2.31$ & 8 & 34 & $0.94 \pm 0.05$ & \multicolumn{2}{|c|}{$154.0 \pm 0.00$} & 11 & 33 \\
\hline & \multicolumn{6}{|l|}{$\mathrm{AU}$} & \multicolumn{7}{|l|}{ SE } \\
\hline & \multicolumn{2}{|l|}{ ss } & \multicolumn{2}{|l|}{ con } & tem & pfa & \multicolumn{2}{|l|}{ ss } & \multicolumn{2}{|l|}{ con } & \multicolumn{2}{|l|}{ tem } & $\mathrm{pfa}$ \\
\hline \multicolumn{14}{|c|}{ Sampling event } \\
\hline 1 & \multicolumn{2}{|c|}{$0.32 \pm 0.16$} & \multicolumn{2}{|c|}{$167.5 \pm 1.29$} & 6.5 & 43 & \multicolumn{2}{|c|}{$0.18 \pm 0.03$} & \multicolumn{2}{|c|}{$185.9 \pm 0.26$} & \multicolumn{2}{|l|}{4.5} & 43 \\
\hline $2 \mathrm{~A}$ & \multicolumn{2}{|c|}{$0.15 \pm 0.04$} & \multicolumn{2}{|c|}{$199.2 \pm 8.55$} & 7 & 43 & \multicolumn{2}{|c|}{$0.70 \pm 0.05$} & \multicolumn{2}{|c|}{$181.3 \pm 4.22$} & \multicolumn{2}{|l|}{5} & 43 \\
\hline $2 \mathrm{~B}$ & \multicolumn{2}{|c|}{$0.35 \pm 0.09$} & \multicolumn{2}{|c|}{$168.5 \pm 0.96$} & 8 & 43 & \multicolumn{2}{|c|}{$0.37 \pm 0.03$} & \multicolumn{2}{|c|}{$191.7 \pm 0.38$} & 5.5 & & 43 \\
\hline $2 \mathrm{C}$ & $0.76 \pm$ & 0.06 & $158.3 \pm 0$ & & 9 & 43 & $1.38 \pm($ & & $185.0 \pm$ & 0.06 & 6 & & 43 \\
\hline $2 \mathrm{D}$ & $0.95 \pm$ & 0.05 & $148.3 \pm 0$ & & 11 & 41 & $0.38 \pm$ & .03 & $183.5 \pm$ & 0.35 & 8 & & 41 \\
\hline 3 & $1.18 \pm$ & 0.11 & $137.9 \pm 0$ & & 13 & 33 & $0.37 \pm$ & .03 & $181.0 \pm$ & 0.85 & 8 & & 33 \\
\hline
\end{tabular}

Suspended solids—Ss $\left(\mathrm{ml} \mathrm{l}^{-1}\right)$, conductivity-con $\left(\mu \mathrm{S} \mathrm{cm}^{-1}\right)$, temperature-tem $\left({ }^{\circ} \mathrm{C}\right)$, Pfankuch index-pfa. Mean \pm standard deviation

Abbreviations for sampling events: $A M$ April/May, JE June, $J Y$ July, $A U$ August, SE September

Table 3 Comparison of differences of the abiotic variables among the sampling events across all six study sites, based on the Friedman test (only significant differences shown, $P<0.05$, df $=4, n=6$ )

\begin{tabular}{llllr}
\hline & Month & & F statistic value \\
\cline { 2 - 3 } & April/May & June & July & August \\
\hline June & & & ss 16.13 \\
July & tem, dis & ss, con & dis & tem 17.82 \\
August & ss, con, tem, pfa & & con 19.87 \\
September & pfa & & dis 20.80 & pfa 20.89 \\
\end{tabular}

See Table 2 for abbreviations

from low channel stability at sites $1-2 \mathrm{C}$ and high stability at sites $2 \mathrm{D}$ and 3 (Table 2).

Macroinvertebrate community: general trends and faunal metrics

The total number of individuals collected was 6631, distributed among 27 taxa. Protonemura sp. was by far the most abundant taxon over the sampling period (PRO-2052 individuals; 31\%), followed by Chironomidae (CHI-1226; 18\%), Baetis sp. (BAE-
863; 13\%), Limnephilidae (LIN-623; 9\%), Rhabdiopteryx sp. (RHA-364; 5\%), Limoniidae (LIM288; 4\%), and Perlodidae (PER-224; 3\%), with the remaining taxa present at lower levels.

The UPGMA cluster analysis based on taxon abundances revealed two distinct but intertwined patterns for grouping of the samples: both site position and month were identified as factors driving the composition of the clusters. In the structure of the six clusters highlighted in Fig. 2, two tendencies emerged: (1) in terms of position, sites tended to be 


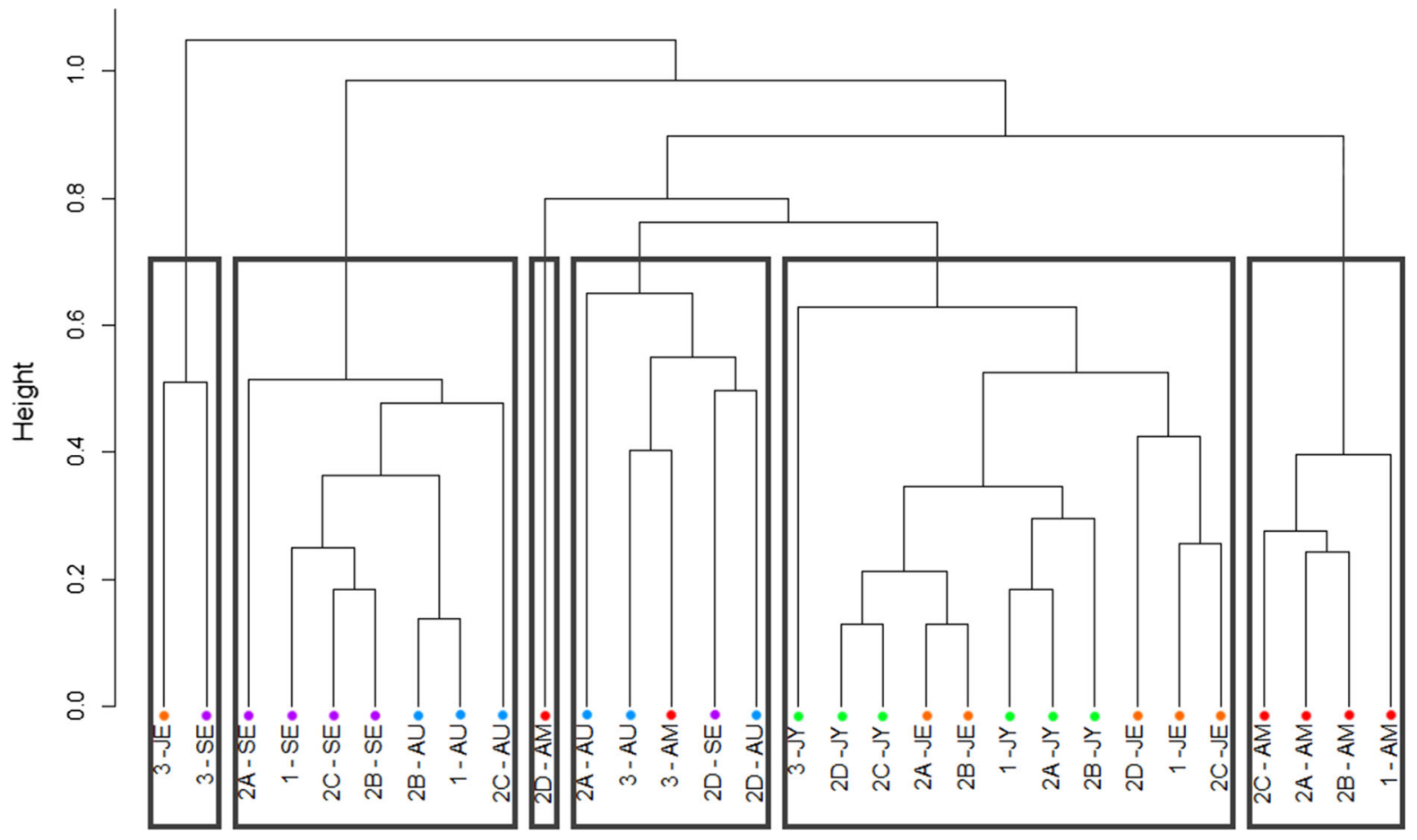

Fig. 2 UPGMA dendrogram based on chord-transformed faunal records. Clusters defined by fusion levels. Abbreviations for samples: site of collection + month code as follows: AM April/May, JE June, JY July, AU August, SE September

clustered into two groups, the first one comprising samples from sites $1-2 \mathrm{C}$ and the second one grouping samples from site $2 \mathrm{D}$ together with the ones from site 3; (2) in terms of time, the months June and July and the months August and September were grouped together. The first sampling event, from April to May, tended to be represented in a unique cluster (Fig. 2).

Density (ind. $/ \mathrm{m}^{2}$ ), taxonomic richness, \% EPT, $\mathrm{H}^{\prime}$, 1-D, and $\mathrm{J}$ showed an overall downstream increasing trend during the study period (Fig. 3). Nevertheless, neither temporal nor spatial patterns, in terms of faunal indices, were found to be significantly different among any pair of sampled months or sites.

Mean values of $\mathrm{H}^{\prime}, 1-\mathrm{D}$, and $\mathrm{J}$ indexes were correlated with the channel stability $(r=-0.488$, $-0.398,-0.436, P<0.05$, respectively), while $\%$ $\mathrm{EPT}, \mathrm{H}^{\prime}$, and $\mathrm{J}$ correlated with the glacial index ( $r=0.381,-0.420,0.366, P<0.05$, respectively). Faunal metrics were not correlated with any other environmental variable.
Macroinvertebrate community: taxon composition versus space, time, environment

In terms of spatial patterns, Limnephilidae, Limoniidae, and Perlodidae presented statistically significant differences in abundances among the sampling sites. Limnephilidae was less abundant at sites 1, 2B, 2C compared to site $3(F=19.44, P<0.05$, df $=5$, $n=5)$. Limoniidae was significantly less abundant at site $2 \mathrm{C}$ compared to site $2 \mathrm{D}(F=16.70, P<0.05$, df $=5, n=5$ ), and Perlodidae less abundant at site 1 compared to site $3(F=16.03, P<0.05, \mathrm{df}=5$, $n=5)$.

In terms of temporal variability, the only taxa whose abundances occasionally differed between months at least at some sites $(P<0.05)$ were Rhabdiopteryx sp., Protonemura sp., Chironomidae, Baetis sp., and Perlodidae (Table 4). For Rhabdiopteryx sp. and Chironomidae, the Friedman test identified significant differences in the overall model $(P<0.05)$ for Protonemura sp., Baetis sp., and Perlodidae differences were found between July and September, June 
(a)

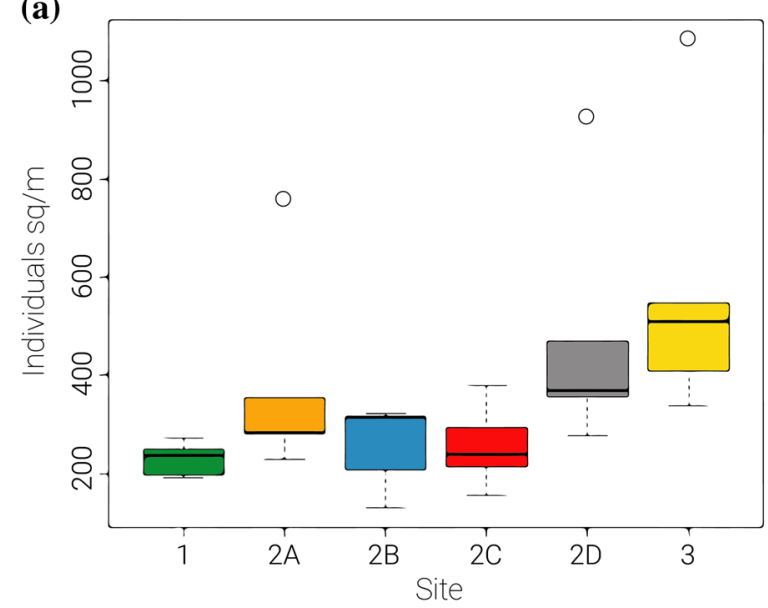

(c)

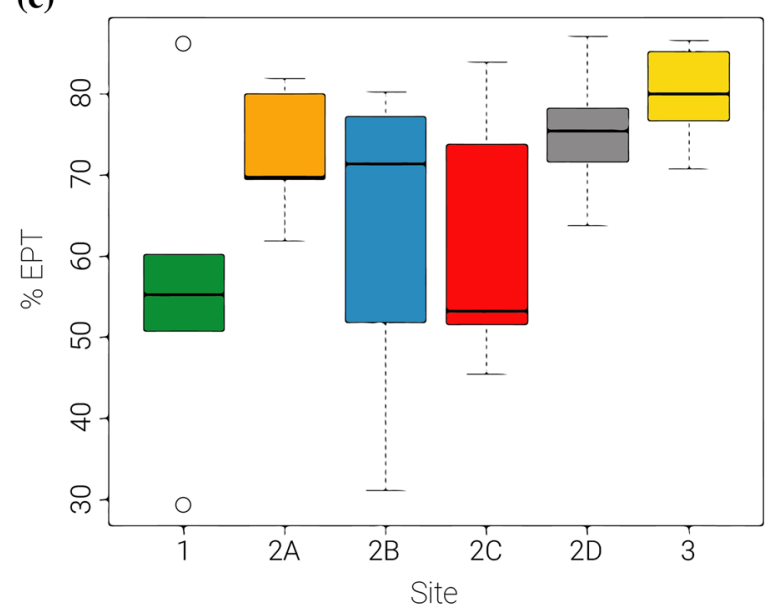

(e)

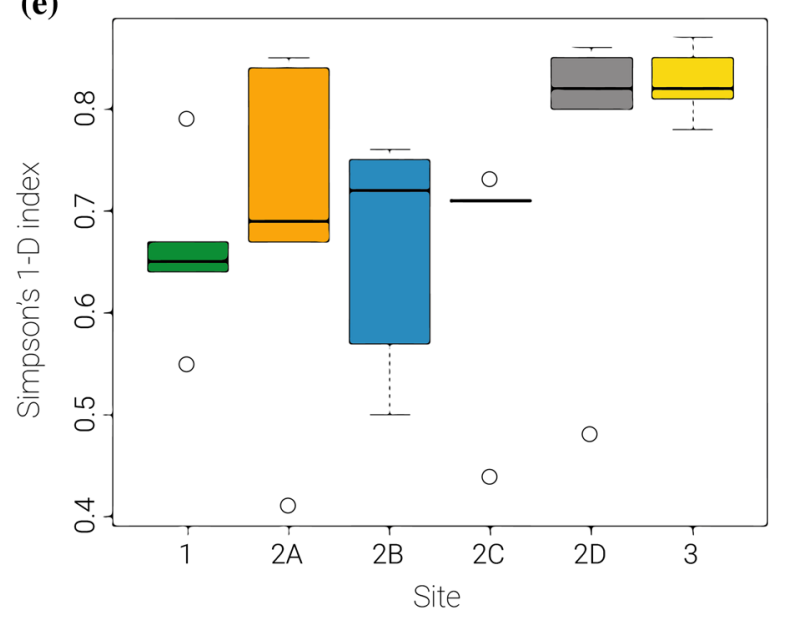

Fig. 3 Box-and-whisker plots for each site, covering the entire study period from April to August and showing a density (ind./ $\left.\mathrm{m}^{2}\right)$; b taxonomic richness; c \%EPT; d Shannon-Weaver $\left(\mathrm{H}^{\prime}\right)$ (b)

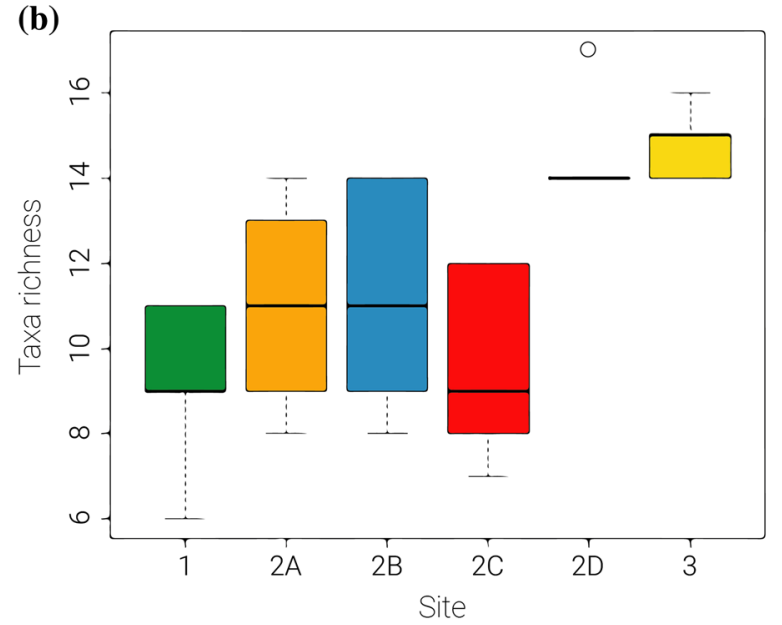

(d)

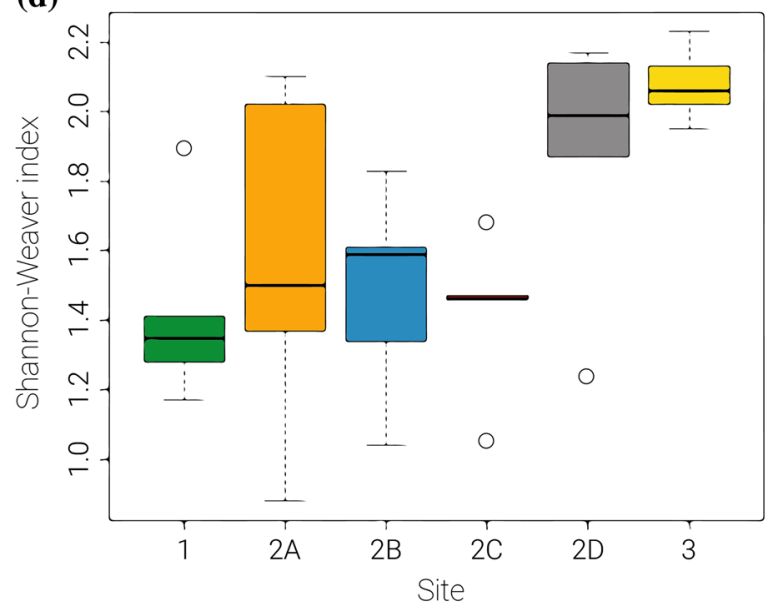

(f)

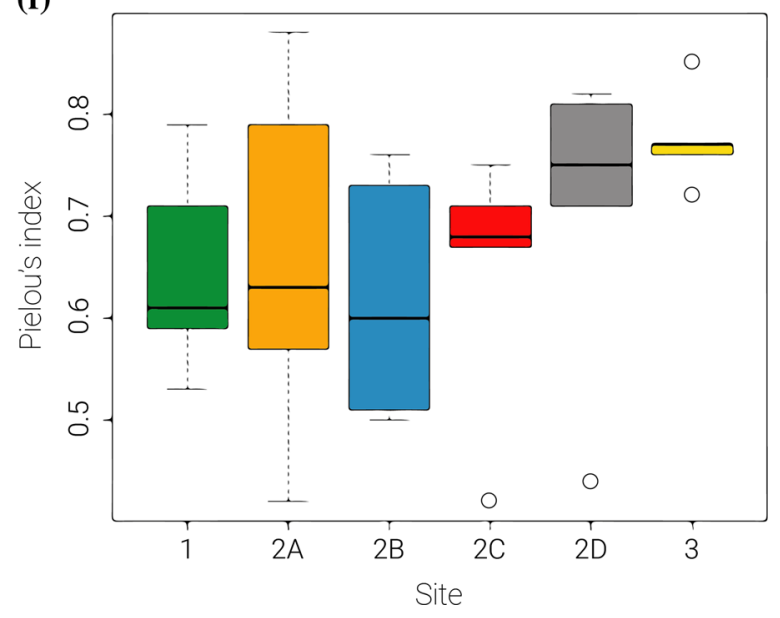

index; e Simpson (1-D) index; f Pielou (J) index. Dots represent values higher/lower than 1.5 times the upper/lower quartile 
Table 4 Comparison of differences of the seven most abundant taxa among the sampling events across all six study sites, based on the Friedman test (only significant differences shown, $P<0.05$, df $=4, n=6$ )

\begin{tabular}{|c|c|c|c|c|c|c|}
\hline & \multicolumn{4}{|l|}{ Month } & & \multirow[t]{2}{*}{ F statistic value } \\
\hline & April/May & June & July & August & & \\
\hline June & & & & & $\mathrm{CHI}^{\mathrm{a}}$ & CHI 10.93 \\
\hline July & & & & & $\mathrm{RHA}^{\mathrm{a}}$ & BAE 12.40 \\
\hline August & & BAE & & & & PER 12.44 \\
\hline \multirow[t]{2}{*}{ September } & & PER & PRO & & & RHA 13.86 \\
\hline & & & & & & PRO 19.60 \\
\hline
\end{tabular}

${ }^{a}$ Indicates a difference in the general macroinvertebrate assemblages model, not linked to any specific couple-by-couple comparison. See text or Appendix-Supplementary Material for abbreviations

Table 5 Correlations between the seven most present taxa and the environmental variables: “**" indicates $P<0.01$ and “*” indicates $P<0.05$

\begin{tabular}{|c|c|c|c|c|c|c|c|}
\hline \multirow[t]{2}{*}{ Environmental variable } & \multicolumn{7}{|l|}{ Taxon } \\
\hline & $\mathrm{CHI}$ & BAE & LIM & RHA & LIN & PRO & PER \\
\hline ss & - & - & - & - & - & - & - \\
\hline con & - & - & - & $0.802 * *$ & - & - & - \\
\hline tem & - & - & - & $-0.448 *$ & - & $0.395 *$ & - \\
\hline $\mathrm{pfa}$ & - & $-0.426^{*}$ & $-0.409 *$ & $0.424 *$ & $-0.817 * *$ & - & $-0.564 * *$ \\
\hline dis & $-0.365^{*}$ & - & - & $-0.462 *$ & - & $0.485 * *$ & - \\
\hline gla & $0.361 *$ & $-0.467 * *$ & $-0.615^{* *}$ & - & $-0.781 * *$ & - & $-0.493 * *$ \\
\hline cha & - & $-0.449^{*}$ & $0.575 * *$ & - & $0.826 * *$ & - & $0.522 * *$ \\
\hline
\end{tabular}

See text or Appendix-Supplementary Material for abbreviations

and August, and June and September, respectively $(P<0.05)$.

Densities of four of the examined taxa (Baetis sp., Limoniidae, Limnephilidae, Perlodidae) were inversely correlated to the Glacial Index and, accordingly, with distance from the glacier (chainage). In contrast, Chironomidae was the only taxon positively correlated with the Glacial Index. The channel stability index was negatively correlated with four taxa (Baetis sp., Limoniidae, Limnephilidae, Perlodidae) and positively correlated with Rhabdiopteryx sp.; Chironomidae and Rhabdiopteryx sp. were positively correlated with discharge. Finally, a strong positive correlation was observed between the density of Rhabdiopteryx sp. and conductivity (Table 5).

Grouping the samples by month and study site, the faunal density showed higher variability in the spatial component (Fig. 4b, average CV 0.562) than in the temporal component (Fig. 4a, average CV 0.405). The same pattern was found for taxonomic richness (average CV 0.241 and 0.182 , respectively). Regarding the other faunal metrics, temporal and spatial components showed similar patterns in CV (Fig. 4).

The CCA showed significance through a permutation test $(F=6.273, P=0.001)$. The amount of variance explained by the collected environmental variables was $67 \%$. The permutation test of each axis showed significance of the first four axes, explaining $61.25 \%$ of the constrained variance (Table 6). The CCA biplots with scaling 1 reinforced the trend shown in the UPGMA clustering, with samplings tending to group based on site position and time of sampling (Fig. 5a, b, respectively). The CCA biplot using scaling 2 (Fig. 6) confirmed the results from the Friedman tests and the correlation analyses: a clear trend showing an affinity of most of the taxa for reduced Glacial Index values, greater distance from the glacier snout, and greater Pfankuch index values was evident. 


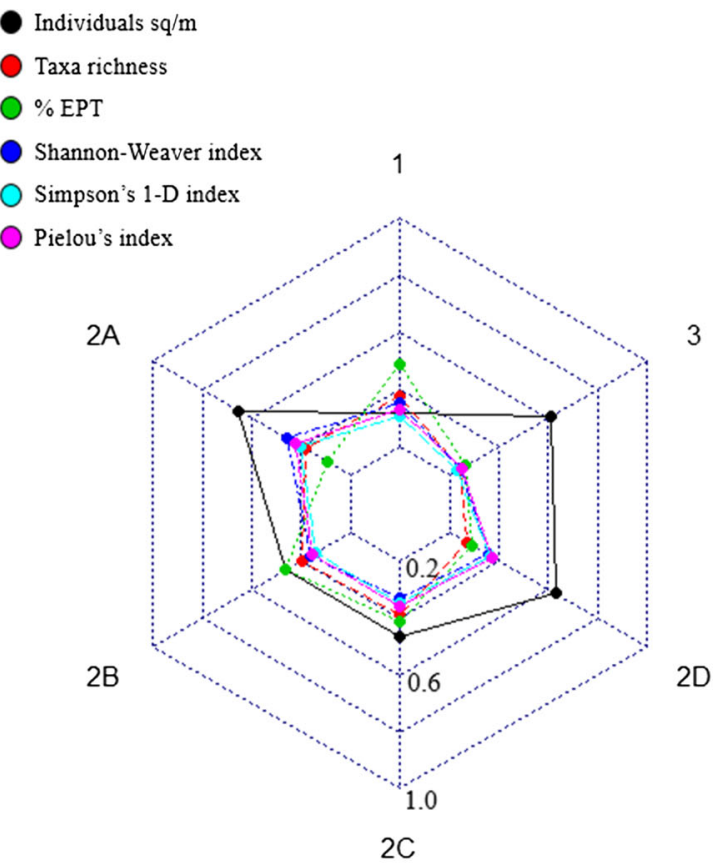

(a)

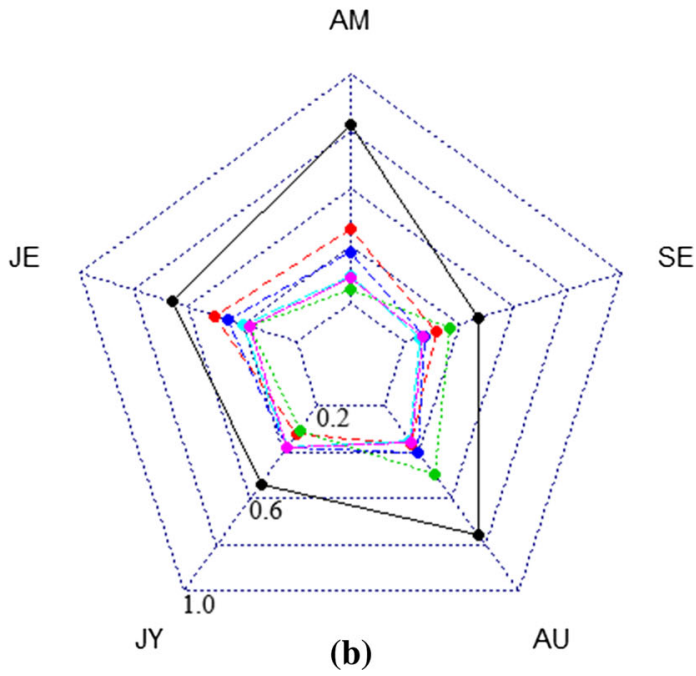

Fig. 4 Radar plots representing coefficient of variability (CV) for a temporal component; $\mathbf{b}$ spatial component

\section{Discussion}

Time and space: influence on faunal composition

The seasonal glacial melt process strongly influenced the dynamics of the benthic macroinvertebrate community, as also reported in similar European glacier- fed systems (Ward, 1994; Burgherr et al., 2002). The cyclical ordination of the sampling events shown in the CCA (Fig. 5b) (Armitage et al., 2001; Leunda et al., 2009) stemmed from a strong seasonality factor for specific groups of macroinvertebrates, whose densities were associated with the variability in the environmental factors. Moreover, the grouping of the sampling events by time was also independently identified by the classification analysis (clusters).

Among the seven most abundant taxa, Rhabdiopteryx sp. and Protonemura sp. showed significant sensitivity to fluctuations of some abiotic factors (Füreder et al., 2005), with two opposite behaviours: the former preferring early- and late-season conditions (high conductivity and low discharge, channel stability, and temperature) and the latter preferring midseason conditions (high discharge and high temperature). Previous studies on the life cycle of Protonemura sp. identified strong interspecific differences in terms of thermal demands, so our taxonomic resolution cannot allow us to infer more regarding the behaviour found in our results (Haidekker \& Hering, 2008). On the other hand, a previous study on Rhabdiopteryx sp. in the alpine region supports our results, clearly showing that there is larval growth during winter snow cover, which explains the prominent emergence in spring (Schütz et al., 2001).

In terms of space, the three taxa whose abundance differed significantly among sites (Limoniidae, Limnephilidae, Perlodidae) were closely associated with sites $2 \mathrm{D}$ and 3 , giving a first confirmation of the progressive presence of new taxa along a glacier-fed stream modelled by Brittain \& Milner (2001).

Temporal versus longitudinal variability

Disentangling the spatio-temporal variability of the benthic assemblage, the $\mathrm{CV}$ analysis of density and taxonomic richness revealed a greater importance of the site-to-site variation than of the month-to-month variation. In our results, there was a clear trend of diminishing $\mathrm{CVs}$ in taxonomic richness, with a general trend, except for site $2 \mathrm{~A}$, of increasing $\mathrm{CV}$ in density-accompanied by increasing channel stability and decreasing glacial influence of the sites (Fig. 4), as also reported in other studies (Burgherr \& Ward, 2001; Lods-Crozet et al. 2001).

Despite the higher abundance and taxonomic richness of macroinvertebrates in sites $2 \mathrm{D}$ and 3, the 
Table 6 Eigenvalues and intraset correlations between the explanatory variables and the four significant axes of CCA analysis

\begin{tabular}{llrrr}
\hline & CCA1 & CCA2 & CCA3 & CCA4 \\
\hline Eigenvalues & 0.321 & 0.204 & 0.150 & 0.056 \\
Proportion explained & 0.269 & 0.170 & 0.126 & 0.047 \\
Cumulative proportion & 0.269 & 0.439 & 0.565 & 0.612 \\
Correlation with axes & & & & \\
Suspended solids (ss) & 0.174 & -0.122 & 0.150 & 0.336 \\
Conductivity (con) & -0.625 & 0.331 & -0.489 & -0.290 \\
Temperature (tem) & 0.483 & -0.390 & -0.112 & 0.366 \\
Pfankuch index (pfa) & -0.789 & -0.553 & 0.098 & -0.173 \\
Discharge (dis) & 0.454 & -0.455 & -0.392 & 0.249 \\
Glacial index (gla) & -0.797 & -0.391 & 0.318 & 0.135 \\
Chainage (cha) & 0.796 & 0.451 & -0.325 & -0.042 \\
Variance explained (constrained) & 0.67 & & & \\
Sum of all eigenvalues & 1.194 & & & \\
Sum of constrained eigenvalues & 0.795 & & & \\
Permutation test overall analysis & $F=6.273, P=0.001$ & & & \\
\hline
\end{tabular}

high CVs exhibited by sites $1-2 \mathrm{C}$ suggest that the community closer to the glacier does not possess a strong core structure, as shown by the sites located more downstream, whose assemblages tended to remain more constant across the sampling period. Indeed, we observed much higher temporal dynamics in taxon turnover in the higher sites, explaining the higher $\mathrm{CV}$ values in comparison to the lower sites, e.g. analysing the July sampling event compared to June, at site 1 , we sampled 7 new taxa, whereas at site 3 , we sampled only 3 new taxa. Thus, it seems that in particular periods, although the local glacial influence may be relatively high, there is the ecological space and opportunity for new taxa to appear outside the classical "windows of opportunity" of spring and late summer/autumn (Uehlinger et al., 2002).

Fit to the conceptual models for glacier-fed streams

The Saldur stream fitted the habitat template for glacier-fed rivers first presented by Milner \& Petts (1994), and furtherly developed by Milner et al. (2001). Indeed, in spatial terms, the model strongly relies on environmental gradients to describe the distribution of benthic macroinvertebrates along a glacier-fed stream, particularly referring to stream temperature and channel stability (Milner \& Petts, 1994; Milner et al., 2001). These factors both followed a clearly defined trend during the sampling period in the Saldur stream.

As expected, water temperature generally increased with increasing distance from the glacier, mostly due to solar radiation and atmospheric heating (Maiolini \& Lencioni, 2001; Kuhn et al., 2011; Khamis et al., 2015). The other main conditioning factor of the conceptual model, channel stability, behaved similarly: the Pfankuch index decreased according to the distance from the glacier (chainage), due to a more stable channel morphology associated with reduced surfaces involved in scouring and deposition processes, and according to reduced glacial influence (Milner \& Petts, 1994). More specifically, a considerable shift in channel stability was identified between the four most upstream sites and the remaining two (2D and 3 ).

In full agreement with the conceptual model, this pattern was also observed for the descriptive metrics density and diversity of the benthic macroinvertebrate assemblages throughout the entire sampling period (Milner et al., 2010). In this framework, the whole set of calculated faunal metrics suggested that the density and the diversity of the sampled assemblages were highly influenced by the spatial patterns and ultimately 

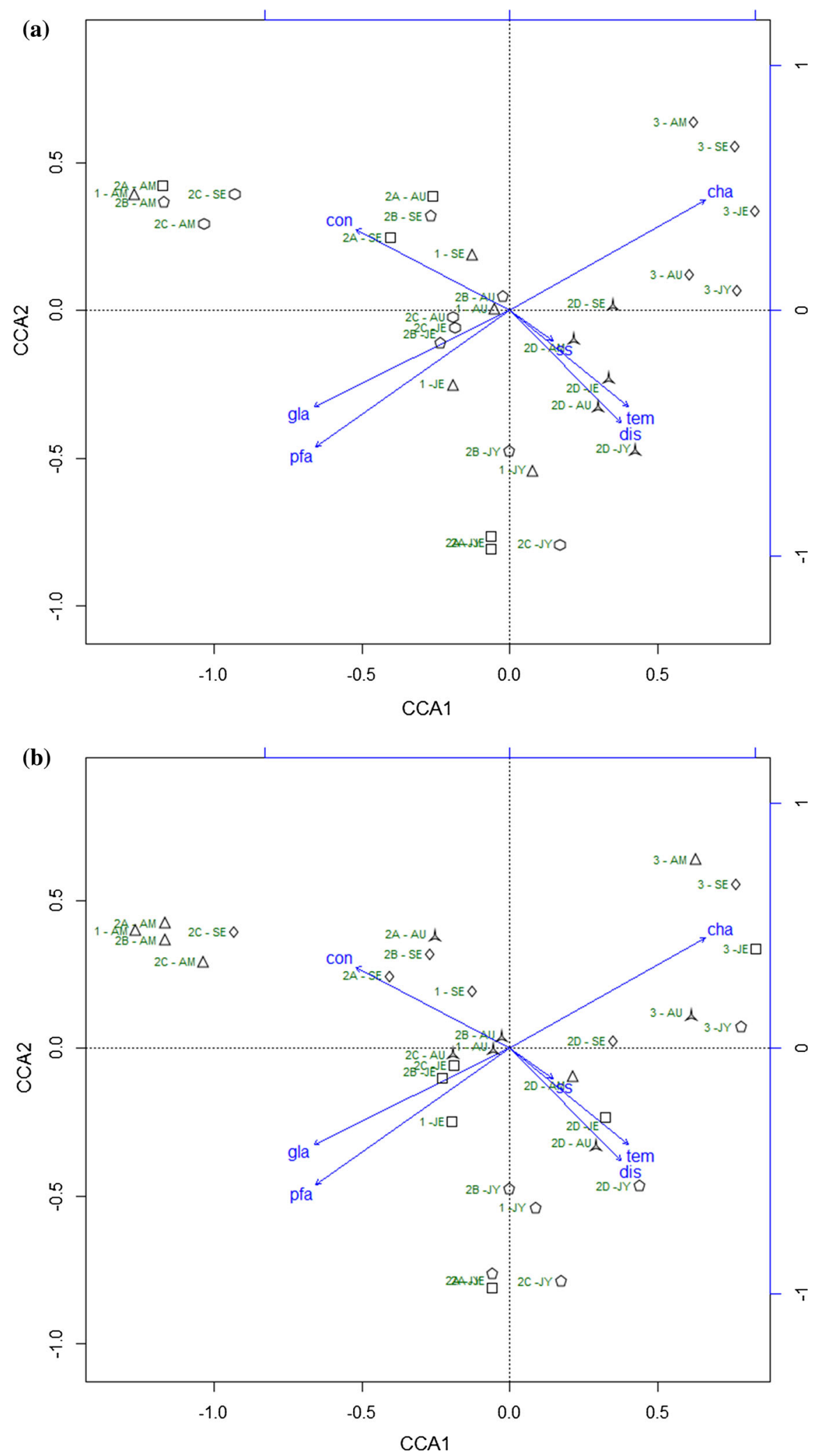
4Fig. 5 CCA biplots, scaling 1, of samplings and environmental variables: a samplings grouped by site position: 1 (triangles), $2 \mathrm{~A}$ (squares), 2B (pentagons), 2C (hexagons), 2D (three-pointed stars), 3 (diamonds); b samplings grouped by sampling time: AM (April/May, triangles); JE (June, squares), JY (July, pentagons), AU (August, three-pointed stars), SE (September, diamonds)

by a reduced environmental harshness-also highlighted by the increased channel stability — derived by decreased glacial influence for sites 2D and 3 (Ilg \& Castella, 2006; Jacobsen \& Dangles, 2012).

Similarly, a more recent spatial analysis in glacierfed streams proposed by Füreder (2007) linked values of a set of faunal metrics to the percentage of glaciation in a catchment. Although our longitudinal transect covered only a limited pattern of glaciation (Table 1), its effect was visible in our results, consistent with the values of diversity, evenness, and number of taxa described by Füreder (2007), for our level of glaciation. In contrast, abundance of macroinvertebrates was consistently lower in our case. Potentially, this is due to the use of a 500- $\mu \mathrm{m}$ mesh-sized sampling net and the strong interannual variability in macroinvertebrate abundances naturally occurring in glacierfed streams (Lods-Crozet et al., 2001; Rüegg \& Robinson, 2004).

The CCA graphically represented this concept in relation to the distribution and succession of taxa along the stream (Fig. 6). Indeed, quadrants I and IV of the Cartesian plane-identifiable as areas of low environmental harshness and glacial influencehosted the highest number of taxa; corroborating the affinity of most of the taxa we retrieved with low values of the Glacial Index, longer distance from the glacier snout, and higher temperature and channel stability (e.g. Castella et al., 2001; Milner et al., 2001; Füreder et al., 2005; Brown et al., 2006). Among the seven most abundant taxa, only chironomids and Rhabdiopteryx sp. showed different behaviours, both related to higher values of the Glacial Index. For Chironomidae, an affinity to high-level glacierised sites is interpreted as a consolidated behaviour (e.g. Niedrist \& Füreder, 2016), whereas for Rhabdiopteryx sp., it may be interpreted as a consequence of the larval

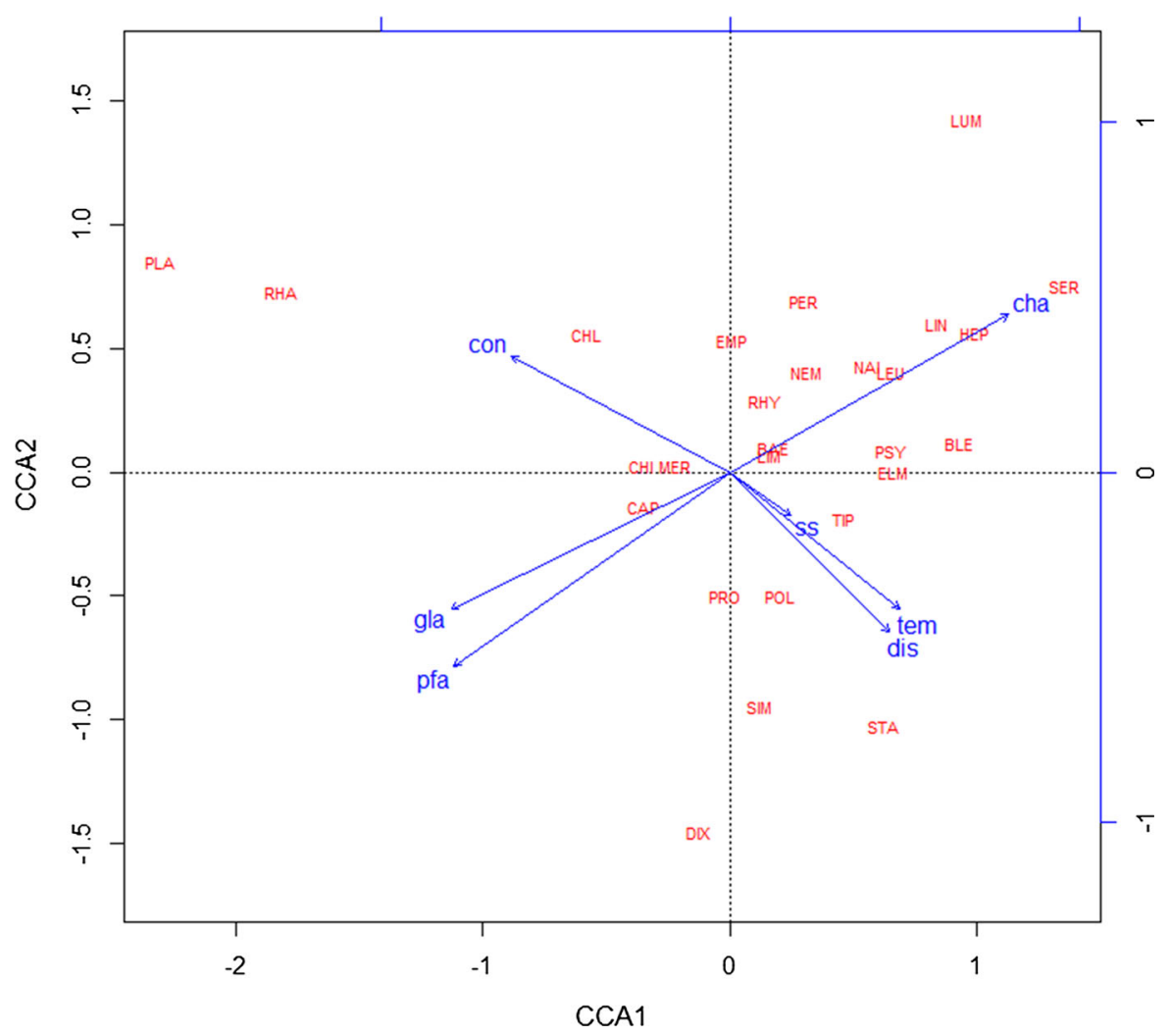

Fig. 6 CCA biplot, scaling 2, of taxa and environmental variables. See Appendix-Supplementary Material for taxon abbreviations 
life cycle with an early emergence, after growth under the snow cover (Schütz et al., 2001): a condition that at the time of sampling was only satisfied by the most upstream sites, associated with higher glacial influence.

In temporal terms, our results fit well with conceptual models and previous studies (Milner et al., 2001: 1844, Fig. 8; Brown et al., 2007b). At site 3, where discharge was measured, a clear inverse relationship between magnitude of discharge and both the abundance and number of taxa was evident for all the sampling events (see Appendix-Supplementary Material).

Finally, the divergent status of site $2 \mathrm{~A}$ may be explained by the presence of a tiny groundwater-fed tributary close to the sampling site, whose influence represented a local discontinuity resulting in an ameliorated and more diverse habitat condition for the benthic macroinvertebrate assemblage (Fig. 3, Brittain et al., 2001; Brittain \& Milner, 2001; Brown et al., 2007c; Khamis et al., 2016).

In summary, the first of the three initial hypotheses was upheld. Indeed, faunal metrics used as a surrogate to qualitatively and quantitatively describe the benthic macroinvertebrate assemblage showed their highest values at sites with reduced glacial influence.

Regarding the second hypothesis, the site-to-site variation was found to be greater than the month-tomonth variation, meaning that the spatial component had a greater effect on the benthic macroinvertebrate assemblage than did the temporal component. Based also on the fact that four out of six sites comprised a stretch whose length was $\sim 500 \mathrm{~m}$, we were expecting the opposite. Moreover, the abiotic factors related to glacier-fed streams, even within a single glacialmelting season, vary within a wide range of values. Thus, these results emphasise the fact that even at a reduced spatial scale, benthic community assemblages may be quite different in terms of both density and number of taxa constituting the community.

Regarding the third and last hypothesis, the Saldur stream showed a set of abiotic factors whose dynamics and relationships were highly consistent with what was previously recorded in other European glacier-fed rivers. Consequently, the distribution of the benthic macroinvertebrates conformed well to the spatial and temporal conceptual models of glacier-fed streams. Nevertheless, our study was limited by being focused on a longitudinal transect not including the stream reach immediately adjacent to the glacier snout. For this reason, our results are only partly comparable to studies previously conducted on other glacier-fed streams.

\section{Conclusions}

Overall, this study provides one of the few characterisations of Italian glacier-fed streams (but see Maiolini \& Lencioni, 2001; Lencioni et al., 2007; Niedrist et al., 2017) and represents a good reference point for future and continuous monitoring of the Saldur stream, also in light of the potential environmental impact of the "run-of-river" hydropower plant and of the regular ILTER activities. Similar analyses may thus constitute the baseline from which natural variability and the variability produced by climate change and/or human activities can be discerned.

Lastly, the study identified an important issue regarding monitoring programmes: even in an extremely temporally variable ecosystem such as a glacierfed stream (where sampling year and season still constitute a great source of faunal variability), the number and position of sampling sites along a longitudinal transect might have a prominent influence when assessing the variation of density and diversity of the benthic macroinvertebrates (e.g. Brown et al., 2009). Because benthic macroinvertebrates are commonly used as powerful bioindicators, this fact must be considered when scheduling long-term monitoring programmes.

Acknowledgements Discharge data were provided by the Hydrographical Office of the Autonomous Province of Bozen. The site MatschlMazia belongs to the national and international long term ecological research networks (LTER-Italy, LTER Europe, and ILTER). The author(s) thank(s) the Department of Innovation, Research and University of the Autonomous Province of Bozen/Bolzano for covering the Open Access publication costs. Finally, we highly appreciate the reviews of two anonymous peers who provided useful comments that greatly improved the quality of the paper.

Open Access This article is distributed under the terms of the Creative Commons Attribution 4.0 International License (http:// creativecommons.org/licenses/by/4.0/), which permits unrestricted use, distribution, and reproduction in any medium, provided you give appropriate credit to the original author(s) and the source, provide a link to the Creative Commons license, and indicate if changes were made. 


\section{References}

APAT \& IRSA-CNR, 2003. Metodi analitici per le acque. Manuali e linee guida 29.

Armitage, P. D., K. Lattmann, N. Kneebone \& I. Harris, 2001. Bank profile and structure as determinants of macroinvertebrate assemblages-seasonal changes and management. Regulated Rivers: Research and Management 17: 543-556.

Borcard, D., F. Gillet \& P. Legendre, 2011. Numerical Ecology with R. Springer Science \& Business Media.

Brittain, J. E. \& A. M. Milner, 2001. Ecology of glacier-fed rivers: current status and concepts. Freshwater Biology 46: 1571-1578.

Brittain, J. E., S. J. Saltveit, E. Castella, J. Bogen, T. E. Bønsnes, I. Blakar, T. Bremnes, I. Haug \& G. Velle, 2001. The macroinvertebrate communities of two contrasting Norwegian glacial rivers in relation to environmental variables. Freshwater Biology 46: 1723-1736.

Brown, L. E., A. M. Milner \& D. M. Hannah, 2006. Stability and persistence of alpine stream macroinvertebrate communities and the role of physicochemical habitat variables. Hydrobiologia 560: 159-173.

Brown, L. E., D. M. Hannah \& A. M. Milner, 2007a. Vulnerability of alpine stream biodiversity to shrinking glaciers and snowpacks. Global Change Biology 13: 958-966.

Brown, L. E., A. M. Milner \& D. M. Hannah, 2007b. Hydroecology of Alpine Rivers. In Hydroecology and Ecohydrology: Past, Present and Future. John Wiley and Sons, Hoboken: 339-360

Brown, L. E., A. M. Milner \& D. M. Hannah, 2007c. Groundwater influence on alpine stream ecosystems. Freshwater Biology 52: 878-890.

Brown, L. E., D. M. Hannah \& A. M. Milner, 2009. ARISE: a classification tool for alpine river and stream ecosystems. Freshwater Biology 54: 1357-1369.

Brown, L. E., K. Khamis, M. Wilkes, P. Blaen, J. E. Brittain, J. L. Carrivick \& S. Hainie, 2018. Functional diversity and community assembly of river invertebrates show globally consistent responses to decreasing glacier cover. Nature Ecology and Evolution 2: 325-333.

Burgherr, P. \& J. V. Ward, 2001. Longitudinal and seasonal distribution patterns of the benthic fauna of an alpine glacial stream (Val Roseg, Swiss Alps). Freshwater Biology 46: $1705-1721$.

Burgherr, P., J. V. Ward \& C. T. Robinson, 2002. Seasonal variation in zoobenthos across habitat gradients in an alpine glacial floodplain (Val Roseg, Swiss Alps). Journal of the North American Benthological Society 21: 561-575.

Campaioli, S., P. F. Ghetti \& A. Minelli, 1994. Manuale per il riconoscimento dei macroinvertebrati delle acque dolci italiane. Provincia autonoma di Trento.

Castella, E., H. Adalsteinsson, J. E. Brittain, G. M. Gislason, A. Lehmann, V. Lencioni \& S. J. Saltveit, 2001. Macrobenthic invertebrate richness and composition along a latitudinal gradient of European glacier-fed streams. Freshwater Biology 46: 1811-1831.

Cauvy-Fraunié, S., R. Espinosa, P. Andino, D. Jacobsen \& O. Dangles, 2015. Invertebrate metacommunity structure and dynamics in an Andean glacial stream network facing climate change. PLoS ONE 10: e0136793.

Cauvy-Fraunié, S., P. Andino, R. Espinosa, R. Calvez, D. Jacobsen \& O. Dangles, 2016. Ecological responses to experimental glacier-runoff reduction in alpine rivers. Nature Communications 7: 12025.

Dray, S. \& A. B. Dufour, 2007. The ade4 package: implementing the duality diagram for ecologists. Journal of Statistical Software 22: 1-20.

Dray, S., P. Legendre \& F. G. Blanchet, 2016. packfor: Forward Selection with permutation (Canoco p.46). R package version $0.0-8 / \mathrm{r} 136$.

Esri, 2014. ArcGIS. Version 10.3.0.4322. Redlands, CA, USA. Esri Inc.

Finn, D. S., K. Khamis \& A. M. Milner, 2013. Loss of small glaciers will diminish beta diversity in Pyrenean streams at two levels of biological organization. Global Ecology and Biogeography 22: 40-51.

Füreder, L., 2007. Life at the edge: habitat condition and bottom fauna of alpine running waters. International Review of Hydrobiology 92: 491-513.

Füreder, L., C. Schütz, M. Wallinger \& R. Burger, 2001. Physico-chemistry and aquatic insects of a glacier-fed and a spring-fed alpine stream. Freshwater Biology 46: 1673-1690.

Füreder, L., C. Vacha, K. Amprosi, S. Bühler, C. M. E. Hansen \& C. Moritz, 2002. Reference conditions of alpine streams: physical habitat and ecology. Water, Air and Soil Pollution: Focus 2: 275-294.

Füreder, L., M. Wallinger \& R. Burger, 2005. Longitudinal and seasonal pattern of insect emergence in alpine streams. Aquatic Ecology 39: 67-78.

Galos, S. \& G. Kaser, 2014. The Mass Balance of Matscherferner 2012/13. University of Innsbruck, project report.

Giersch, J. J., S. Jordan, G. Luikart, L. A. Jones, F. R. Hauer \& C. C. Muhlfeld, 2015. Climate-induced range contraction of a rare alpine aquatic invertebrate. Freshwater Science 34: 53-65.

Giersch, J. J., S. Hotaling, R. P. Kovach, L. A. Jones \& C. C. Muhlfeld, 2017. Climate-induced glacier and snow loss imperils alpine stream insects. Global Change Biology 23: 2577-2589.

Habler, G., M. Thöni \& B. Grasemann, 2009. Cretaceous metamorphism in the Austroalpine Matsch Unit (Eastern Alps): the interrelation between deformation and chemical equilibration processes. Mineralogy and Petrology 97: 149-171.

Haidekker, A. \& D. Hering, 2008. Relationship between benthic insects (Ephemeroptera, Plecoptera, Coleoptera, Trichoptera) and temperature in small and medium-sized streams in Germany: a multivariate study. Aquatic Ecology 42: 463-481.

Huss, M., 2011. Present and future contribution of glacier storage change to runoff from macroscale drainage basins in Europe. Water Resources Research 47: 1-14.

Huss, M. \& R. Hock, 2018. Global-scale hydrological response to future glacier mass loss. Nature Climate Change 8: 135-140.

Huss, M., G. Jouvet, D. Farinotti \& A. Bauder, 2010. Future high-mountain hydrology: a new parameterization of 
glacier retreat. Hydrology and Earth System Sciences 14: 815-829.

Huss, M., B. Bookhagen, C. Huggel, D. Jacobsen, R. S. Bradley, J. J. Clague, M. Vuille, W. Buytaert, D. R. Cayan, G. Greenwood, B. G. Mark, A. M. Milner, R. Weingartner \& M. Winder, 2017. Toward mountains without permanent snow and ice. Earth's Future 5: 418-435.

Ilg, C. \& E. Castella, 2006. Patterns of macroinvertebrate traits along three glacial stream continuums. Freshwater Biology 51: 840-853.

Jacobsen, D. \& O. Dangles, 2012. Environmental harshness and global richness patterns in glacier-fed streams. Global Ecology and Biogeography 21: 647-656.

Jacobsen, D., O. Dangles, P. Andino, R. Espinosa, L. Hamerlik \& E. Cadier, 2010. Longitudinal zonation of macroinvertebrates in an Ecuadorian glacier-fed stream: do tropical glacial systems fit the temperate model? Freshwater Biology 55: 1234-1248.

Jacobsen, D., A. M. Milner, L. E. Brown \& O. Dangles, 2012. Biodiversity under threat in glacier-fed river systems. Nature Climate Change 2: 361-364.

Jiménez Cisneros, B. E., T. Oki, N. W. Arnell, G. Benito, J. G. Cogley, P. Döll, T. Jiang \& S. S. Mwakalila, 2014. Freshwater resources. In Climate Change 2014: Impacts, Adaptation, and Vulnerability. Part A: Global and Sectoral Aspects. Contribution of Working Group II to the Fifth Assessment Report of the Intergovernmental Panel on Climate Change. Cambridge University Press, Cambridge: 229-269.

Jordan, S., J. J. Giersch, C. C. Muhlfeld, S. Hotaling, L. Fanning, T. H. Tappenbeck \& G. Luikart, 2016. Loss of genetic diversity and increased subdivision in an endemic alpine stonefly threatened by climate change. PLoS ONE 11: e0157386.

Khamis, K., L. E. Brown, D. M. Hannah \& A. M. Milner, 2016. Glacier-groundwater stress gradients control alpine river biodiversity. Ecohydrology 9: 1263-1275.

Khamis, K., L. E. Brown, A. M. Milner \& D. M. Hannah, 2015. Heat exchange processes and thermal dynamics of a glacier-fed alpine stream. Hydrological Processes 29: 3306-3317.

Khamis, K., D. M. Hannah, L. E. Brown, R. Tiberti \& A. M. Milner, 2014. The use of invertebrates as indicators of environmental change in alpine rivers and lakes. Science of the Total Environment 493: 1242-1254.

Kuhn, J., P. Andino, R. Calvez, R. Espinosa, L. Hamerlik, S. Vie, O. Dangles \& D. Jacobsen, 2011. Spatial variability in macroinvertebrate assemblages along and among neighbouring equatorial glacier-fed streams. Freshwater Biology 56: $2226-2244$.

Le, S., J. Josse \& F. Husson, 2008. FactoMineR: an R package for multivariate analysis. Journal of Statistical Software 25: $1-18$.

Legendre, P. \& E. D. Gallagher, 2001. Ecologically meaningful transformations for ordination of species data. Oecologia 129: 271-280.

Legendre, P. \& L. F. Legendre, 2012. Numerical Ecology, Vol. 24. Elsevier, New York.

Lencioni, V., B. Maiolini, L. Marziali, S. Lek \& B. Rossaro, 2007. Macroinvertebrate assemblages in glacial stream systems: a comparison of linear multivariate methods with artificial neural networks. Ecological Modelling 203: 119-131.

Leunda, P. M., J. Oscoz, R. Miranda \& A. H. Ariño, 2009. Longitudinal and seasonal variation of the benthic macroinvertebrate community and biotic indices in an undisturbed Pyrenean river. Ecological Indicators 9: $52-63$.

Lods-Crozet, B., E. Castella, D. Cambin, C. Ilg, S. Knispel \& H. Mayor-Simeant, 2001. Macroinvertebrate community structure in relation to environmental variables in a Swiss glacial stream. Freshwater Biology 46: 1641-1661.

Maiolini, B. \& V. Lencioni, 2001. Longitudinal distribution of macroinvertebrate assemblages in a glacially influenced stream system in the Italian Alps. Freshwater Biology 46: $1625-1639$.

Milner, A. M. \& G. E. Petts, 1994. Glacial rivers: physical habitat and ecology. Freshwater Biology 32: 295-307.

Milner, A. M., J. E. Brittain, E. Castella \& G. E. Petts, 2001. Trends of macroinvertebrate community structure in glacier-fed rivers in relation to environmental conditions: a synthesis. Freshwater Biology 46: 1833-1847.

Milner, A. M., A. L. Robertson, K. A. Monaghan, A. J. Veal \& E. A. Flory, 2008. Colonization and development of an Alaskan stream community over 28 years. Frontiers in Ecology and the Environment 6: 413-419.

Milner, A. M., L. E. Brown \& D. M. Hannah, 2009. Hydroecological response of river systems to shrinking glaciers. Hydrological Processes 23: 62-77.

Milner, A. M., J. E. Brittain, L. E. Brown \& D. M. Hannah, 2010. Water sources and habitat of Alpine streams. Alpine Waters. Springer, Berlin Heidelberg: 175-191.

Milner, A. M., K. Khamis, T. J. Battin, J. E. Brittain, N. E. Barrand, L. Füreder \& A. J. Hodson, 2017. Glacier shrinkage driving global changes in downstream systems. Proceedings of the National Academy of Sciences 114: 9770-9778.

Murdoch, D. \& E. D. Chow, 2018. Ellipse: Functions for Drawing Ellipses and Ellipse-Like Confidence Regions. R package version 0.4.1. https://CRAN.R-project.org/ package $=$ ellipse

Niedrist, G. H. \& L. Füreder, 2016. Towards a definition of environmental niches in alpine streams by employing chironomid species preferences. Hydrobiologia 781: 143-160.

Niedrist, G. H., R. Alber, A. Scotti, H. Rauch, S. Vorhauser, T. Kiebacher \& R. Bottarin, 2017. Aquatic invertebrates along the progression of glacial and non-glacial streams in Matsch Valley (South Tyrol, Italy). Gredleriana 17: 129-140.

Oksanen, J., F. G. Blanchet, M. Friendly, R. Kindt, P. Legendre, D. McGlinn, P. R. Minchin, R. B. O’Hara, G. L. Simpson, P. Solymos, M. Henry H. Stevens, E. Szoecs \& H. Wagner, 2018. vegan: Community Ecology Package. R package version 2.5-2.

Pfankuch, D. J., 1975. Stream Reach Inventory and Channel Stability Evaluation. US Department of Agriculture Forest Service, Region, 1.

R Core Team, 2016. R: A language and environment for statistical computing. Version 3.3.0. Vienna, Austria. R Foundation for Statistical Computing. 
Robinson, C. T., U. Uehlinger \& M. Hieber, 2001. Spatiotemporal variation in macroinvertebrate assemblages of glacial streams in the Swiss Alps. Freshwater Biology 46: 1663-1672.

Rott, E., M. Cantonati, L. Füreder \& P. Pfister, 2006. Benthic algae in high altitude streams of the Alps - a neglected component of the aquatic biota. Hydrobiologia 562: 195-216.

Rüegg, J. \& C. T. Robinson, 2004. Comparison of macroinvertebrate assemblages of permanent and temporary streams in an Alpine flood plain, Switzerland. Archiv für Hydrobiologie 161: 489-510.

Sansoni, G. \& P. F. Ghetti, 1998. Atlante per il riconoscimento dei macroinvertebrati dei corsi d'acqua italiani. Provincia autonoma di Trento (IS), Provincia autonoma di Trento.

Schädler, B. \& R. Weingartner, 2010. Impact of climate change on water resources in the alpine regions of Switzerland. Alpine Waters. Springer, Berlin, Heidelberg: 59-69.
Schütz, C., M. Wallinger, R. Burger \& L. Füreder, 2001. Effects of snow cover on the benthic fauna in a glacier-fed stream. Freshwater Biology 46: 1691-1704.

Snook, D. L. \& A. M. Milner, 2001. The influence of glacial runoff on stream macroinvertebrate communities in the Taillon catchment, French Pyrénées. Freshwater Biology 46: 1609-1623.

Uehlinger, U., K. Tockner \& F. Malard, 2002. Ecological windows in glacial stream ecosystems. Eawag News 54: 20-21.

Venables, W. N. \& B. D. Ripley, 2002. Modern Applied Statistics with S, 4th ed. Springer, New York.

Viviroli, D. \& R. Weingartner, 2008. "Water Towers" - A Global View of the Hydrological Importance of Mountains. Mountains: Sources of Water, Sources of Knowledge. Springer, Netherlands: 15-20.

Ward, J. V., 1994. Ecology of alpine streams. Freshwater Biology 32: 277-294. 